\title{
EDUCATION FOR LIBRARY SERVICE TO YOUTH IN FIVE COUNTRIES
}

\section{Denice Adkins and Susan Higgins}

In this study, youth services instructors from five countries (Australia, Canada, New Zealand, the United Kingdom, and the United States) were surveyed as to the content of youth-oriented classes they had taught between 2000 and 2003. As anticipated, a content analysis of those descriptions revealed that the youth-oriented library curriculum was heavily dominated by children's and young adult materials. Management of the youth library and foundations of youth library services were less frequently emphasized. Descriptive content is remarkably similar between regions, but looking at an analysis of the content with regard to national differences suggests additions to curricula based on the needs of each country.

\section{Background}

In the past century, there has been extensive documentation of education for library service to youth (ELSY) in library and information science (LIS), but little focus on the content of that education. In 1986, the Section on Children's Libraries, International Federation of Library Associations and Institutions, recommended that ELSY cover topics such as children's materials, programming, collection development and youth services management, children's psychology, culturally and socially different children, and reviewing (Glistrup et al. 1986, 1346). Many of the International Federation of Library Associations and Institutions' course recommendations are found in the curriculum of these five countries; however, there has not been a comparative study of ELSY conducted on a national or international basis.

The authors examined the provision of ELSY in five countries: the United States, Canada, the United Kingdom, Australia, and New Zealand. We define ELSY as comprising those courses or subjects available through university study that deal with youth-oriented topics such as children's or young adult literature, youth services, or school librarianship. The content and focus of ELSY in each of these countries is analyzed. The research questions addressed in this exploratory study are as follows:

1. What subject content is taught in each of these countries?

2. Is there a substantive difference in courses and course content between these regions?

ELSY has a longer history in the United States, Canada, and the United Kingdom than it does in Australia and New Zealand. However, instructors in all areas have demonstrated their concern for and commitment to ELSY in the literature. Previous documentation of ELSY is summarized by country in the following.

New Review of Children's Literature and Librarianship, Vol. 12, No. 1, 2006 ISSN 1361-4541 print/1740-7885 online/06/010033-16 


\section{United States}

In the United States, library education programs are accredited by the American Library Association. Formal youth-oriented library education has been available since 1899, when the Pratt Institute first offered a course in children's librarianship (Forbes 1992, 158). In these early years, course content revolved around children's literature, promotion of that literature, and child psychology (Fasick 1990,19). The teaching of children's literature has received a great deal of attention in the years since. Numerous reports focus on the teaching of children's literature (e.g. Adamson 1987; Benne 1987; Gross 1967; Howard 1987; Laughlin 1982; Lundin and Cubberly 1995; Rosen 1987). The content of non-literature courses has not been as thoroughly described in LIS literature, but a summary of articles suggests coverage of non-print materials; management of youth libraries; information needs of youth; programming and storytelling; use of computers and audiovisual media in youth librarianship; booktalks; and promotion of library services to children and adults. Summarizing research about ELSY in the United States, Eliza Dresang notes that no surveys of the content of youth services curricula can be found (1999, para. 23).

\section{Canada}

Like their neighbors to the south, Canadian schools are accredited by the American Library Association (Wood 1997, 28). Also like their neighbors to the south, Canadian library schools offer courses on children's literature, children's services, young adult literature, and evaluation of youth literature. Nonetheless, they contribute a unique perspective to ELSY: courses devoted to Canadian children's literature. Ronald Jobe (1990, 81-2) and Lissa Paul (1989, 44-5) noted that Canadian literature does not get as much coverage in children's literature courses as American and British literature - and according to Paul, 'the most important thing about Canadian stories is that they are our stories, our family stories, and they help locate and define us' $(1989,43)$.

\section{United Kingdom}

Starting in 1884, librarians in the United Kingdom were chartered by the Library Association upon successful completion of a rigorous examination. Children's services were not included in the examination until the 1933 revision, and in 1950 a specialist certificate in children's services was added as an option (Bramley 197, 134, 156). Since 1999, the Chartered Institute of Library and Information Professionals has accredited programs of library education (Huckle 2004, 3). ELSY is a challenging issue. Helen Pain's (1987) survey of 13 LIS programs in the United Kingdom found only one postgraduate course and nine undergraduate courses in youth services librarianship, with the majority of the curriculum focused on school librarianship (Bramley 1981, 8). Judith Elkin's 
survey of 16 LIS programs concluded that 'There is an almost total lack of specialist offerings in children's or schools' librarianship' (1992, 152). Youth services specializations were offered by only four schools at the postgraduate level (Elkin 1994, 31). Nonetheless, limited specialized curriculum was supplemented the opportunity to write theses and direct generalized course work toward youth environments (Elkin 1997, 70). ELSY offerings in the United Kingdom, as enumerated in several articles, included youth literature, information resources for youth, school librarianship, non-print materials, youth services, youth in society, and youth information needs (Denham 1994; Elkin 1992; Lonsdale and Spink 1987; Pain 1987). In the general category of youth literature was an emphasis on genres, age appropriateness, the publishing industry, and adaptations of youth literature (Denham 1994, 88-103).

\section{Australia}

Although university-based LIS education was not available until 1960, Australian libraries provided training courses for general librarianship as well as a 1-week children's librarianship course in 1954 (Harvey and Higgins 2003, 150; Rochester 1997, 17-19, 43). When Sara Innis Fenwick conducted her Fulbright visit to Australia in the 1960s, graduate library education was still in gestation, being developed at the University of New South Wales and the Royal Institute of Technology. 'Schools offering [LIS education] would make it possible to provide professional education for librarians to work with children, and to include a specialization for school librarianship' (Fenwick 1965, 130). Until 1980, youth specialists were certified by the Library Association of Australia (Poston-Anderson 1986, 20). After 1980, tertiary institutions assumed responsibility for all librarian qualifications, including the bachelor's degree in LIS, the postgraduate diploma, and the Master's degree (Harvey and Higgins 2003, 151). These generalist programs were supplemented with youth-oriented electives, including print and non-print resources, development, services, and management (Poston-Anderson 1986, 25-7), as well as practical field experience in reader advisory, collection development, programming, and book selection (Gagiero 1982, 23-5).

\section{New Zealand}

Initial training of New Zealand's youth librarians took place overseas. While children's libraries had existed since 1909, New Zealand's first two children's librarians were educated in the United States in the 1930s (McCahon 1998, 44). The New Zealand Library Association created a youth services certificate program in 1941 and developed the New Zealand Library School in 1946, awarding a generalist certificate and diploma. In 1980, the Library School's diploma program was transferred to the Victoria University of Wellington, and in 1996 the diploma became a Master's degree (Richardson 1998, 94-5). Sara Innis Fenwick's assessment of youth-oriented curriculum called for increased course coverage 
of 'reading guidance, story telling, services for exceptional children, and uses of audiovisual materials' (1975, 39).

The LIS establishment in each of these five countries has made library service to youth a priority, and all areas have been active in providing training for youth librarians. LIS schools in each of these countries make some sort of youthoriented coursework available to students. Youth literature plays a significant part of the curriculum, according to these reports, along with other non-print materials. Services such as programming and reader advisory suggest a strong desire to acquaint youth with literature as a pleasurable experience. The historic similarity in curricular components is striking, but a comparison of curriculum has not been undertaken. This study attempts to fill the gap in the literature identified by Dresang, an absence of information on ELSY contents, placing findings into an international context.

\section{Method}

In order to learn more about ELSY currently offered to students, we surveyed LIS faculty who taught such courses between 2000 and 2003 in the five countries of interest, asking them to describe their ELSY courses. We then analyzed those course descriptions for trends and similarities. The survey we used was web-based and extensively pre-tested before administration. Questions were adapted to region-specific terminology for each location. For instance, 'course' in the United States became 'subject' in Australia and 'module' in the United Kingdom. The instrument was available to respondents between 1 March and 31 May 2004.

Two different methods were used to invite faculty to participate. For LIS schools accredited by the American Library Association, full-time and adjunct instructors were identified based on an evaluation of school websites. A total of 191 North American instructors received a mass e-mail invitation, of whom 71 responded. Seven invitations were returned as having invalid addresses or delivery problems. Another 16 individuals indicated that they did not want to participate, either by using the survey service's 'decline' function or by e-mailing the survey administrators. The survey return rate for US and Canadian recipients was 42 percent. At the same time that the mass survey mailing was sent to US and Canadian instructors, an invitation to participate was sent to the directors of 17 LIS programs in the United Kingdom, six programs in Australia, and one in New Zealand. Directors were asked to forward the invitations to the relevant faculty members or adjunct instructors. Fifteen responses resulted from these 24 invitations. Of the 88 total usable responses, 86 instructors identified their country of origin: the United States (64), the United Kingdom (11), Canada (seven), Australia (three), and New Zealand (one). Due to the very small number of participants from Australia and New Zealand, these countries were combined into one region for further analysis. 
Survey questions about course content are reproduced in Appendix A. Information solicited from the instructors included the course title, catalog description, topics covered, and instructional goals. Most respondents took this information directly from their syllabi or outlines. Because syllabi are aimed toward a student audience, and are used to communicate course content to that audience in a relatively succinct manner, we considered this information to be a valid indicator of course content. The researchers, engaged in the same professional endeavors as the respondents, read the course content within the context of a communication between the course providers and consumers (Manning and Cullum-Swan 1994, 464).

A content analysis method was used to identify common instructional areas, based on the information provided about goals and content. Each course was considered a separate unit of analysis. Descriptions were conceptually analyzed for the appearance of specific content, dictionary-type indicators rather than unique components, as the researchers sought evidence of commonalities and consensus in their review. Because syllabi tend to be direct and succinct, the assumption was that inclusion of a topic was an indicator of intensity, and there was no example of any course content being presented as negative or neutral. We further assumed that topics appearing very frequently in the description suggested increased coverage of that topic in the class. In final data analysis, we have computed the frequency with which indicators appear in course descriptions, and we interpret that data in light of the philosophies of LIS instruction.

\section{Category Construction}

Previous studies suggested several content areas for youth-oriented instruction, including child development, informational needs of youth, children's and young adult literature, evaluation criteria for literature, management of youth services, promotion of youth services, and programming. Nonetheless, while some previous studies took a very deep look into one specific subject (i.e. children's literature), few examined course content from a variety of youthoriented subjects. Furthermore, most of these articles were written prior to 1996. The rise of computer technology in the late 1990s and early 2000s may have expanded course content.

To allow for that expansion, and to consider topics from a variety of courses, Adkins analyzed course descriptions and classified the data into 178 codes representing current course content (Sarantakos 1995, 215). Higgins provided a reliability check by coding a selection of course listings separately and comparing results. Codes and categories were renegotiated and redeveloped when intercoder agreement was not possible. The resulting coding scheme contained 100 codes for ELSY content, which fell into five overarching categories: Youth as Persons; Youth Librarianship; Managing the Youth Library; Youth Materials; and Youth Services. 
Codes included in the Youth as Persons category were youth culture and identity; youth development; multicultural youth; special needs youth; reading ability; caregivers' needs; youth needs and interests; reading needs and interests; and information needs and interests. Codes included in the Youth Librarianship category were youth advocacy; censorship/intellectual freedom; history of youth services; philosophy of youth services; professional resources; professional development; and youth services research. In the Managing the Youth Library category were general management; budgeting; developing goals and objectives; developing policies; and staff management. The Youth Services category included general services; history of youth services; delivery, promotion, and evaluation of youth services; facilities; organizing/cataloging youth materials; reader guidance; youth reference; outreach; collaboration with external agencies; services for special groups; programming; and various programming techniques such as storytelling, booktalking, and puppetry. Codes included in the Youth Materials category were selection, promotion, evaluation, and use of youth materials, general materials and a listing of various formats such as electronic and non-print; general literature, including a list of various genres such as chapter books and graphic novels; history of youth publishing; literary characteristics of youth literature; illustrations; and author/illustrator studies.

After agreement on codes and categories was established, a final comparison was conducted to establish intercoder reliability. 'The reliability of a content analysis study refers to its stability, or the tendency for coders to consistently re-code the same data in the same way over a period of time ... and accuracy, or the extent to which the classification of a text corresponds to a standard or norm' (Palmquist 1999, para. 10). Results were subject to a crosstabs evaluation (SPSS 12.0), using Cohen's kappa to determine intercoder reliability. Kappa values ranged between 0.806 and 1.00 for each category. Kimberly Neuendorf suggests that reliability coefficients of '.80 or greater' are acceptable (2002, 143).

\section{Limitations}

There are some limitations to the methods we used to solicit responses and to interpret results, which we acknowledge. First, the population surveyed may not be entirely representative of the population of LIS faculty teaching youthoriented courses. Response rates for the US and Canadian samples were low, which may have been due to the attempt to reach all instructors directly. The technique used to reach Australian, New Zealand, and UK respondents, sending a message to LIS program deans that was then forwarded to one or more ELSY instructors, may have produced a greater return rate by appearing to be endorsed by higher-level administration. Due to the low response rate, there may be youth-oriented courses that were not reported and thus not included in our final analysis. Finally, while we have had both US and international teaching 
experience, we are both US educated. Our interpretation of course content may be different from others' interpretations.

\section{Results}

The largest number of responses came from the United States. The 64 US respondents included nine full professors, 14 associate professors, 16 assistant professors, and 22 clinical or adjunct faculty. The seven Canadian respondents included three associate professors, two assistant professors, and two lecturers. The 11 respondents from the United Kingdom included one professor, one senior lecturer, and three lecturers. The Australian and New Zealand faculty included three lecturers and one instructor.

Instructors provided information on 139 youth-oriented classes: 106 from the United States, 22 from Canada, seven from the United Kingdom, and four in Australia/New Zealand. Initially, courses were analyzed by title. Each word or concept in the title was classified into three broad items: the age of the youth audience to be reached (children, young adults, or both); the venue from which the librarian would operate (public or school library); and curriculum categories (as indicated by our coding scheme). All course information was then contentanalyzed for a deeper look into course content. During that analysis, all words and concepts were analyzed by frequency of appearance within the description and summarized by curriculum category.

\section{Course Title}

The course title is the first indication of the kind of information presented in that course. A brief overview of course titles, presented in Table 1, indicates a relatively even distribution between classes focused on children, those focused on young adults, and those accommodating both audiences. Regionally, however, there are some differences. In the United States, an equal number of courses were focused on young adults and children. In the United Kingdom and Canada, courses were more likely to focus on children. Generalized 'youth' courses appeared in all regions, but were more common in Australia/New Zealand and the United Kingdom (Table 1).

By course title, approximately one-quarter of all classes were focused on school library settings. A much smaller number of classes were specifically focused on youth in the public library setting. The majority of course titles, almost one-half of all titles in all regions, emphasized materials (also called literature or resources). By comparison, Youth Services comprise a much smaller share of the ELSY curriculum. Specialized courses such as storytelling, programming, and reference service to youth were offered in the United States, but, even so, Youth Services remained a relatively small portion of the curriculum in all regions. 
TABLE 1

Instructional concepts, as found in 139 youth services course titles

\begin{tabular}{|c|c|c|c|c|c|c|c|c|c|c|}
\hline \multirow[b]{2}{*}{ Concept } & \multicolumn{2}{|c|}{$\begin{array}{c}\text { Australia/ } \\
\text { New Zealand }\end{array}$} & \multicolumn{2}{|c|}{ Canada } & \multicolumn{2}{|c|}{$\begin{array}{l}\text { United } \\
\text { Kingdom }\end{array}$} & \multicolumn{2}{|c|}{$\begin{array}{l}\text { United } \\
\text { States }\end{array}$} & \multicolumn{2}{|c|}{ Total } \\
\hline & $n$ & $\%$ & $n$ & $\%$ & $n$ & $\%$ & $n$ & $\%$ & $n$ & $\%$ \\
\hline \multicolumn{11}{|l|}{ Audience } \\
\hline Children & & & 7 & 32 & 2 & 29 & 25 & 24 & 34 & 24 \\
\hline $\begin{array}{l}\text { Young Adults/Teens/ } \\
\text { Adolescents }\end{array}$ & & & 2 & 9 & & & 25 & 24 & 27 & 19 \\
\hline $\begin{array}{l}\text { Children and Young } \\
\text { Adults/Youth }\end{array}$ & 2 & 50 & 5 & 23 & 2 & 29 & 19 & 18 & 28 & 20 \\
\hline \multicolumn{11}{|l|}{ Venue } \\
\hline Public Libraries & & & 2 & 9 & & & 4 & 4 & 6 & 4 \\
\hline School Libraries & & & 6 & 27 & 2 & 29 & 26 & 25 & 34 & 24 \\
\hline \multicolumn{11}{|l|}{ Course content } \\
\hline $\begin{array}{l}\text { Youth as Persons } \\
\text { Youth Librarianship }\end{array}$ & & & & & & & 1 & 1 & 1 & 1 \\
\hline Managing the Youth & & & & & & & 5 & 5 & 5 & 4 \\
\hline \multicolumn{11}{|l|}{ Library } \\
\hline Youth Materials & 2 & 50 & 10 & 45 & 3 & 43 & 50 & 47 & 65 & 47 \\
\hline Youth Services & 1 & 25 & 3 & 14 & 1 & 14 & 15 & 14 & 21 & 15 \\
\hline Materials and Services & 1 & 25 & 2 & 9 & & & 8 & 8 & 11 & 8 \\
\hline Information Literacy & 1 & 25 & 1 & 5 & 1 & 14 & 2 & 2 & 4 & 3 \\
\hline Total number of courses & 4 & 100 & 22 & 100 & 7 & 100 & 106 & 100 & 139 & 100 \\
\hline
\end{tabular}

\section{Course Descriptions}

Course titles are by necessity short and pithy. To examine course content more closely, we asked instructors to provide catalog descriptions for their courses, topics covered, and instructional goals. Of the 139 courses for which information was submitted, detailed descriptions were available for 124. To determine the importance of particular concepts in ELSY, course information was analyzed for the frequency with which content variables appeared in the course information.

Throughout all regions, children and young adults get almost equal coverage in course descriptions. While children are mentioned more frequently in Canada and the United Kingdom, young adults prevail in the United States and Australia/New Zealand. There is clearly some overlap in the coverage of these two service populations - as can be seen in class titles that combine 'children and young adults.' If a service venue was presented in ELSY course descriptions, that venue was generally the school library. In addition to classes specifically devoted to school librarianship, other classes included information about information literacy programs originating from school libraries or services suitable for school and public libraries. Only in Australia were public libraries mentioned in course descriptions more frequently than school libraries. The appearance of public libraries in course descriptions went hand-in-hand with a mention of school 
libraries. Seldom was public library service to youth mentioned as an explicit emphasis area of a course.

As can be seen by the summary information presented in Table 2, the category Youth Materials dominates ELSY education. This category includes audiovisual and electronic resources for youth as well as toys. Regional literature makes an appearance as well, with Canada, Australia/New Zealand, and one region of the United States emphasizing works created by authors from the area. Evaluating and selecting youth materials plays a large part of the Youth Materials curriculum as well. The strong Youth Materials emphasis occurs across all regions (Table 2).

The second most-mentioned ELSY area in each country was Youth Services. This category encompassed both public services (such as programming and reference) and behind-the-scenes services (such as outreach and webpage development). In general, public services were more often mentioned than were behind-the-scenes services. Although 'programming' as a topic was covered, techniques for programming were seldom mentioned in course descriptions. Two notable exceptions to this were booktalking and storytelling. Youth as Persons was the third most frequently mentioned category in course descriptions. This category made a strong showing in the United States and Australia/New Zealand, and less so in Canada and the United Kingdom. Reading

\section{TABLE 2}

Frequency of appearance of instructional concepts in 124 youth services course descriptions

\begin{tabular}{|c|c|c|c|c|c|c|c|c|c|c|}
\hline \multirow[b]{2}{*}{ Concept } & \multicolumn{2}{|c|}{$\begin{array}{c}\text { Australia/ } \\
\text { New Zealand }\end{array}$} & \multicolumn{2}{|c|}{ Canada } & \multicolumn{2}{|c|}{$\begin{array}{c}\text { United } \\
\text { Kingdom }\end{array}$} & \multicolumn{2}{|c|}{$\begin{array}{l}\text { United } \\
\text { States }\end{array}$} & \multicolumn{2}{|c|}{ Total } \\
\hline & $n$ & $\%$ & $n$ & $\%$ & $n$ & $\%$ & $n$ & $\%$ & $n$ & $\%$ \\
\hline \multicolumn{11}{|l|}{ Audience } \\
\hline Children & 1 & 25 & 18 & 90 & 3 & 60 & 57 & 60 & 79 & 64 \\
\hline $\begin{array}{l}\text { Young Adults/Teens/ } \\
\text { Adolescents }\end{array}$ & 3 & 75 & 12 & 60 & 2 & 40 & 63 & 66 & 80 & 65 \\
\hline \multicolumn{11}{|l|}{ Venue } \\
\hline Public Libraries & 3 & 75 & 1 & 5 & 1 & 20 & 25 & 26 & 30 & 24 \\
\hline School Libraries & 2 & 50 & 12 & 60 & 4 & 80 & 57 & 60 & 75 & 60 \\
\hline \multicolumn{11}{|l|}{ Course Content } \\
\hline Youth as Persons & 5 & 125 & 17 & 85 & 4 & 80 & 138 & 145 & 155 & 125 \\
\hline Youth Librarianship & 1 & 25 & 13 & 65 & 1 & 20 & 92 & 97 & 107 & 86 \\
\hline Managing the Youth & 2 & 50 & 11 & 55 & 1 & 20 & 62 & 65 & 76 & 61 \\
\hline \multicolumn{11}{|l|}{ Library } \\
\hline Youth Materials & 20 & 500 & 108 & 540 & 13 & 260 & 526 & 557 & 667 & 538 \\
\hline Youth Services & 10 & 250 & 47 & 235 & 5 & 100 & 228 & 240 & 290 & 234 \\
\hline Total number of courses & 4 & 100 & 20 & 100 & 5 & 100 & 95 & 100 & 124 & 100 \\
\hline
\end{tabular}

Note: Percentages are derived by dividing the frequency figure by the number of courses per region. 
ability, information needs, youth development, and youth culture were the codes most frequently identified in all regions.

Youth Librarianship and Managing the Youth Library were the two leastemphasized categories in ELSY. Youth Librarianship, which was only moderately emphasized in the United States and Canada, dealt largely with the role librarians play in serving youth. Issues of censorship/intellectual freedom received the most emphasis in this category, mentioned in all regions except the United Kingdom. The category that received the least coverage in all regions except Australia/New Zealand was Managing the Youth Library. General management was covered in roughly one-third of classes in Canada and the United States, while policy development was covered more extensively in Australia/New Zealand and Canada.

Results for individual codes highlight some curricular emphases. Strong areas in Australia include general youth services, collection development, literary genres, and young people's reading abilities. In Canada, the leading areas are youth services delivery, young people's reading interests, collection development, materials evaluation, non-print and electronic media, and the history of youth literature. Curriculum in the United Kingdom emphasizes general youth services, youth materials selection, multimedia and electronic materials, and information literacy. In the United States, dominant curricular areas were youth development, programming, censorship/intellectual freedom, collection development, selection and evaluation of youth materials.

\section{Discussion}

\section{What Content is Being Taught in These Regions?}

This question speaks to the issue of how youth services librarians are being prepared for their professional duties and what ELSY instructors perceive librarians' roles to be. In all regions, Youth Materials forms the backbone of youth services education. The majority of the 'Materials' category is given over to youth literature; however, there is additional emphasis on non-print materials, audiovisual materials, electronic and web resources, and toys. Given a philosophy of libraries as storehouses of materials waiting for users, the educational focus on youth materials makes sense. A competing philosophy of librarianship is that libraries exist to connect users to information, as mediated through the library's materials and services. The educational support for this philosophy can be seen in the relatively strong emphasis on Library Services to Youth: programming, reader advisory, youth reference, outreach, and so forth. These services are generally provided with the intent of connecting young people to libraries and literature in a meaningful way. The emphasis on young people as individuals in their own right also supports this view, by encouraging librarians to look at children's needs and accept those needs as valid. 
In all regions, there is considerably less emphasis on the study of the Youth Services Librarian and Managing the Youth Services Library. The lack of attention to youth services librarians in Australia/New Zealand and the United Kingdom may well be due to the dearth of ELSY courses available. With a limited number of contact hours between students and faculty, those precious hours need to be devoted to the topics deemed most important - in this case, materials and services. In the United States, with over twice as much weight in this category as in Australia/New Zealand or the United Kingdom, the study of censorship/ intellectual freedom drives a large part of this curriculum. Youth advocacy is a small part of the curriculum. This is surprising, given societal views of young people as powerless and vulnerable.

The dearth of coverage for Managing the Youth Library was another surprise. Despite a flurry of articles illustrating the strong management component of youth services librarianship (e.g. Benne 1991; Holt 1997; Ivy 1987; Minudri 1981), management is a topic little addressed in youth services education. This lack may be partially explained by student motivations and partially by the structure of the library education system. It has been suggested that students do not see the need for management-type courses until they are out in the workplace (Curry 2000, 332). Additionally, students may receive management education in other classes, such as school library administration or a general library management course. It is important to note that greater management responsibility most often involves promotion out of the specialty. Given the strong need for management skills in youth librarianship, however, it is unfortunate that this aspect of the curriculum is neglected.

\section{Is there a Substantive Difference in Course Content Between Regions?}

Looking at the broad content categories presented in Table 2, there does not seem to be much of a difference in terms of emphasis. Youth Materials makes up the bulk of courses in all regions, Youth Services and Youth as Persons take second and third place, respectively, with Youth Librarianship and Managing the Youth Library receive very little coverage.

However, certain small differences were revealed in looking at the full coding scheme. In the Youth as Persons category, every region has some coverage of youth development and reading ability. Youth information needs and reading interests are covered in each region except the United Kingdom. However, categories such as youth caregivers' needs, multicultural youth, and special needs youth were not widely covered. In the Youth Librarianship category, no subject area was covered by all four regions, although issues of censorship/intellectual freedom were covered in three (and may have been covered, but not explicitly mentioned, in the United Kingdom). Professional resources for youth librarians and youth services research were also covered in all regions except Australia/New Zealand. Coverage of professional development for 
children's librarians, youth advocacy, history, and philosophy of youth services tended to occur only in the United States or Canada. In the Managing the Youth Services Library category, three out of four regions cover policy creation and staff management, the United Kingdom being the exception. General management is covered in all regions except Australia/New Zealand. Budgeting was covered in two regions (Canada and the United States), and development of goals and objectives covered in only one (the United States).

All regions covered general service to youth in the Youth Services category. Three out of four regions covered service evaluation, collection development, reader advisory, reference service, collaboration with youth agencies, programming, and storytelling. Only Canada and the United States covered the history and promotion of youth services, youth services facilities, cataloging youth materials, outreach, and various forms of programming. Only one region covered service to special groups, seasonal, and summer reading programs (Canada), picture book programs, and readers' theater (United States).

Youth Materials were covered in all four regions. Promotion and evaluation of youth materials, multimedia and electronic resources, and genres were covered in each region. Materials selection, materials in general, Internet resources, and informational materials were covered in three out of four regions, along with literature in general, characteristics of literature, fantasy, fiction, picture books, regional, and informational literature.

\section{Conclusion}

In all of the presented assessments, it should be understood that coverage is based only on the descriptions provided by the instructors. Content might well be delivered that is not represented in the course description. This international study was intended to seek commonality between instructors, and a high degree of consistency between the four areas has been found.

While the study was geared toward commonalities, it also suggests some avenues for curriculum development in each of these regions based on individual regional needs. For Australia/New Zealand, recommended course content would include a focus on multicultural youth and their literature. Indeed, this may already be covered; both countries have substantial indigenous populations, and New Zealand librarians seem to be actively working with the Maori population (Lilley 1998). Also, programming coverage might be expanded to reach multicultural populations. Since youth librarianship is relatively new to both countries, some consideration of professional development might be covered for students who may be geographically isolated from other youth librarians.

Given Canada's two language populations (English and French), relations with First Nations (indigenous) peoples, and Toronto's reputation for diversity, increased focus on the informational needs of multicultural youth would also be beneficial. An increased focus on evaluating youth services might be a useful 
companion to the intensive youth services curriculum, along with greater analysis of youth culture.

The United Kingdom has limited youth services offerings, but greater possibilities for exploring youth services outside youth specializations. However, coursework that might be beneficial would include a focus on youth culture, youth caregivers, and youth advocacy, along with information about a professional support network for youth services librarians. Management may well be covered in non-specialist courses, but youth library services such as reader guidance and reference service to youth ought to have a place in the youth services curriculum, as might an increased focus on programming beyond using literature in the curriculum.

The United States offers a broad array of youth service topics, but falls down in certain places. Most notable is the lack of focus on types of programming, including summer reading programs, which most public youth services librarians will be involved in at some point in their careers. Coverage of the philosophy behind youth services and research into youth services is minimal, as is the coverage of multicultural and special needs youth. In a country that prides itself on diversity, these areas should be increased.

For all regions, more focus on electronic materials, Internet resources, and management will be necessary to accommodate changing work environments. Foundational knowledge of educational and economic policy as regards the welfare of children globally might also be incorporated in youth services courses, as might a cross-cultural study of comparative librarianship.

Library and information science educators and practitioners share a common theory: that people's lives can be improved through the delivery of information. Nowhere is this need more obvious than in the provision of library services to children. Internationally, children and teenagers are seen as having information rights, including being able to access age-appropriate information and participate in literacy-building activities. Literacy itself is seen as fundamental to full participation in the adult world of work, and one of the goals of childhood is to develop that literacy. Libraries play a role in this development by providing information, services, and activities designed to enhance literacy. Nonetheless, these services do not magically appear for the asking; they are dependent on the provision of faculty with expertise in the youth work and courses that focus on the youth themselves.

\section{References}

ADAMSON, L. G. 1987. Results of the children's literature assembly's survey of teaching in U.S. colleges and universities. Bookbird 25: 11-15.

BENNE, M. 1897. Course development: From a gleam in the eye to a full-term product. Top of the News 43(2): 177-82.

. 1991. Children's librarian as manager. In Principles of children's services in public libraries. Chicago, IL: American Library Association, 30-65. 
BRAMLEY, G. 1981. Apprentice to graduate: A history of library education in the United Kingdom. London: Clive Bingley.

CURRY, A. 2000. Canadian LIS education: Trends and issues. Education for Information 18(4): $325-37$.

DENHAM, D. 1994. Children's literature: A reflective approach to learning. International Review of Children's Literature and Librarianship 9(2): 88-103.

DRESANG, E. 1999. Education for youth services specialization in librarianship: Background paper, April, 113 paras. Available online at: http://www.lis.fsu.edu/Includes/ Content/Faculty/dresang2.html (accessed 25 March 2004).

ELKIN, J. 1992. The education and training of children's librarians. International Review of Children's Literature and Librarianship 7(3): 151-4.

1994. Children's modules. Library Association Record 96: 33.

1997. Specialist provision in LIS education. In The education of library and information professionals in the United Kingdom, edited by J. Elkin and T. Wilson. London: Mansell, 1997. 53-82.

FASICK, A. M. 1990. Carrying on the tradition: Training librarians for children's services. In Lands of pleasure: Essays on Lillian H. Smith and the development of children's libraries, edited by Adele M. Fasick, Margaret Johnston and Ruth Osler. Metuchen, NJ: Scarecrow Press. 19-32.

FENWICK, S. I. 1965. School and children's libraries in Australia: A report to the Children's Libraries Section of the Library Association of Australia. Melbourne, Australia: F. W. Cheshire for the Library Association of Australia.

. 1975. Library services for children in New Zealand school and public libraries: $A$ report to the New Zealand Library Association. Wellington: New Zealand Council for Educational Research, New Zealand Library Association. 36.

FORBES, M. E. 1992. Children and youth services: Education for librarianship. In Ideals and standards: The history of the University of Illinois Graduate School of Library and Information Science, 1893-1993, edited by W. C. Allen and R. F. Delzell. Urbana-Champaign, IL: Graduate School of Library and Information Science, University of Illinois. 157-72.

GAGIERO, F. 1982. In-service training for children's librarians at the CamberwellWaverley regional library. Orana 18(1): 23-5.

GLISTRUP, E. et al. 1986. Education and training-Why and how? In Education and training of librarians in children's librarianship, edited by E. Glistrup. Ballerup: Bibliotekscentralens Forlag. 128-39.

GROSS, E. H. 1967. The teaching of children's literature. Wilson Library Bulletin 42: 199205.

HARVEY, R. and S. HIGGINS. 2003. Defining fundamentals and meeting expectations: Trends in LIS education in Australia. Education for Information 21: 149-57.

HOLT, L. E. 1997. Dream jobs: a career guide for the ambitious children's librarian. School Library Journal 43: 29-31.

HOWARD, E. F. 1987. Teachers of children's literature discussion group: Networking in action. Top of the News 43: 189-92. 
HUCKLE, M. 2004. European accreditation of library and information science studies, European Bureau of Library, Information, and Documentation Associations, 14 pp. Available onnline at: http://www.eblida.org/eblida/meetings/Council/council04/Estoril_Seminar_Item7_MHuckle_May04.pdf (accessed 5 December 2004). IVY, B. A. 1987. Developing managerial skills in children's librarians. Library Trends 35 : 449-61.

JOBE, R. A. 1990. Teaching children's and young adult literature in Canada. International Review of Children's Literature and Librarianship 5(2): 71-85.

LAUGHLIN, M. 1982. Approaches to teaching children's literature. Journal of Education for Librarianship 23: 23-8.

LILLEY, S. 1998. Treaty of Waitangi issues and New Zealand librarianship. In Library service in New Zealand, edited by A. D. Richardson and R. McCahon. Lower Hutt: The Open Polytechnic of New Zealand. 1-10.

LONSDALE, R. and J. SPINK. 1987. Children's books in the education of librarians at the College of Librarianship Wales, Aberystwyth. Signal 54: 203-9.

LUNDIN, A. H. and C. W. CUBBERLEY. 1995. Teaching children's literature: a resource guide, with a directory of courses. Jefferson, NC: McFarland \& Company.

MANNING, P. K. and B. CULLUM-SWAN. 1994. Narrative, content, and semiotic analysis. In Handbook of qualitative research, edited by Norman K. Denzin and Yvonna S. Lincoln. Thousand Oaks, CA: Sage Publications.

MCCAHON, R. 1998. Library service to children and young adults. In Library service in New Zealand, edited by A. D. Richardson and R. McCahon. Lower Hutt: The Open Polytechnic of New Zealand. 44.

MINUDRI, R. 1981. Management of youth services: Political, financial, and social implications. In Managers and missionaries: Library services to children and young adults in the information age, edited by L. Edmonds. Urbana-Champaign, IL: University of Illinois Graduate School of Library and Information Science. 1727.

NEUENDORF, K. A. 2002. The content analysis guidebook. Thousand Oaks, CA: Sage Publications.

PAIN, H. 1987. Professional education and children's and school librarianship. Library Association Review 89(3): 131-35.

PALMQUIST, R. A. 1999. Content analysis, 31 August, 14 paras. Available online at: http:// www.gslis.utexas.edu/ palmquis/courses/content.html (accessed 5 December 2004).

PAUL, L. 1989. Teaching children's literature in Canada. Signal 58: 39-50.

POSTON-ANDERSON, B. 1986. Australia. In Education and training of librarians in children's librarianship, edited by E. Glistrup. Ballerup: Bibliotekscentralens Forlag. 13-32.

RICHARDSON, A. 1998. Education for librarianship. In Library service in New Zealand, edited by A. D. Richardson and R. McCahon. Lower Hutt: The Open Polytechnic of New Zealand. 94-5.

ROCHESTER, M. K. 1997. Education for librarianship in Australia. London: Mansell.

ROSEN, E. M. 1987. Educators and practitioners: a cooperative pattern of curriculum review. Top of the News 43: 185-8. 
SARANTAKOS, S. 1995. Social research. Riverina, NSW: Charles Sturt University.

WOOD, K. 1997. Professional education: Historical overview. In The education of library and information professionals in the United Kingdom, edited by J. Elkin and T. Wilson. London: Mansell. 1-30.

Denice Adkins (author to whom correspondence should be addressed), Assistant Professor, SISLT, University of Missouri, 303 Townsend Hall, Columbia, MO 65211, USA. Tel: +1 573884 9804; Fax: +1 573884 4944; E-mail: adkinsde@missouri.edu

Susan Higgins, Assistant Professor and SLIS, The University of Southern Mississippi, 118 College Drive \#5146, Hattiesburg, MS 39406-0001, USA.

\section{Appendix A: ELSY-related Questions from the Web-based Survey of Instructors}

All terminology differences are included in the question:

1. Subject/Course/Module Title (i.e. 'Children's Literature')?

2. Is this subject/module more applicable to school or public libraries?

3. In the last three academic years, how many times has this subject/course/ module been offered?

4. In the last three years, approximately how many students have enrolled in this subject/course/module?

5. What is the catalog description for this subject/course/module?

6. What topics do you cover when you teach this subject/course/module? (For example, storytelling, types of literature, outreach, etc.)

7. What are your instructional goals for this subject/course/module? What do you want your students to remember in five years, for example? 